\title{
Az elektronikus közigazgatás és a területi kutatások kapcsolatáról
}

\section{Connection between e-government and spatial research}

\author{
ZSOM BRIGITTA
}

ZSOM Brigitta: statisztikus, Központi Statisztikai Hivatal; PhD-hallgató, Eötvös Loránd Tudományegyetem, Földrajz- és Földtudományi Intézet, Budapest; zsom.brigi@gmail.com

KULCSSZAVAK: elektronikus közigazgatás, a közigazgatás földrajza, információs kommunikációs technológiák

ABSZTRAKT: A tanulmány célkitűzése, hogy választ adjon arra a kérdésre, hogy a területi kutatásokban (földrajz és regionális tudomány) van-e létjogosultsága az elektronikus közigazgatás vizsgálatának, ha igen, milyen kérdések megválaszolásában lehet szerepe. A kérdés vizsgálata azért fontos, mert az információs kommunikációs technológiák rohamos mértékủ fejlődése áthatja az élet minden területét, így a közigazgatást is. Az utóbbi évtizedben számos országban a közszféra legnagyobb mértékủ technológiai innovációja az elektronikus közigazgatás bevezetése volt. A tanulmány első harmadában tisztázom az elektronikus közigazgatás fogalmát, a második harmadában sorra veszem azon főbb szakterületeket, amelyek a téma vizsgálatával foglalkoznak, a harmadik harmadában pedig a közigazgatási földrajz történeti áttekintésével foglalkozom.

Az igazgatásszervezés és a szakpolitikai vizsgálatok is megfogalmazzák, hogy a legfőbb kihívások egyike a befogadó e-közigazgatás megteremtése, a digitális szakadék leküzdése, amely társadalmi, gazdasági és területi különbségekben egyaránt megnyilvánul. A földrajznak és a regionális tudománynak ezeknek a területi különbségeknek a feltárásában és mérséklésében lehet szerepe. A közigazgatási földrajz kutatásában általánosságban két alapprobléma jelenik meg, a területi szintek számának és jellegének meghatározása, valamint a horizontális lehatárolás problémája. A közigazgatás-fejlesztési folyamatokat erősen áthatja az elektronizáció, így a közigazgatási földrajzi vizsgálatok során, térkategóriák lehatárolásakor és meghatározásakor érdemes lehet a tér- és időbeli elérések mellett a virtuális tér jelenségét is figyelembe venni, e szempont integrálása is feladata lehet a területi kutatásoknak.

Brigitta ZSOM: statistical analyst, Hungarian Central Statistical Office; PhD student, Institute of Geography and Earth Sciences, Eötvös Loránd University, Budapest; zsom.brigi@gmail.com

KEYWORDS: e-government, information communication technologies, public-administration geography

ABSTRACT: The main goal of this study is to find out if spatial research (such as geography and regional science) can play a role in examining e-government or not. If the answer is yes, which questions are relevant for a geographer in this research topic?

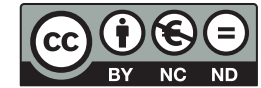


Firstly, the definition of e-government and the difference between the meaning of e-government, e-governance and e-administration are described. Examining e-government is a fresh and new, interdisciplinary research area. Some of the disciplines which analyze e-government, such as economics, public-administration management, history of science and information-society policy have their own definitions and keep their own focus on a specific topic when examining e-government. Secondly, the aim of this study is to investigate the main research questions of other disciplines.

Finally, the history and the role of public-administration geography are described as well and we tried to determine a way of how to interpret the main research questions of publicadministration geography when attempting to investigate e-government from a spatial aspect.

With regard to public-administration management and the information-society policy one of the main challenges consists in creating an inclusive e-government, overcoming the digital divide, which manifests itself in social, economic and regional inequalities. Geography and regional science could have a role in describing these types of inequalities and methods to reduce them.

Generally speaking, public-administration geography has two main problems: on the one hand, determining the number and the nature of government entities (such as local authorities, provinces, regions) and on the other hand, the challenging issue of horizontal extension. The development processes of public administration have a strong connection with electronization. Geography and regional science could involve e-government and the aspect of virtual space to solve the public-administration geography's main problems.

\section{Bevezetés}

Az elektronikus közigazgatás az információs társadalom szerves részét képezi. Önmagában az információs társadalom fogalmáról nem létezik egységes nézet, azt mindenki más értelemben használja (Balogh 2006); ehhez hasonlóan az elektronikus közigazgatás mibenlétét is nehéz körülhatárolni. Az e-közigazgatás megfogalmazására annyi definíció fordul elő, ahány egyén, szervezet, fórum alkalmazza azt (Dinesh 2007). Budai (2009) tanulmányában azt fogalmazza meg, hogy az elektronikus közigazgatás olyan új, interdiszciplináris, több szaktudománnyal érintkező kutatási terület, amelynek a kutatási tárgya, módszerei, nyelvezete és elméleti alapjai még körvonalazódnak.

Több tudományterület felől közelíthető meg az elektronikus közigazgatás fogalmának magyarázata: a jogi, a közgazdasági és igazgatásszervezési diszciplínák, valamint a szakpolitikák és a nemzetközi szervezetek fogalommeghatározásaik során egyaránt szembesültek azzal a problémával, hogy mind a magyar, mind a nemzetközi szakirodalomban egymással részben átfedő, részben más jelentéstartalommal rendelkező kifejezések keringenek, amelyeket sokszor helytelenül, néha szinonimaként alkalmaznak. Az elektronikus közigazgatás mellett az elektronikus kormányzás, valamint az elektronikus ügyintézés kifejezésekkel találkozhatunk a szakirodalomban. A magyar szakirodalom nyelvi zavara, fogalomütközése a nemzetközi szakirodalom öröksége, ahol az e-government, e-governance és e-administration szófordulatok léteznek.

A tanulmány célkitűzése, hogy tisztázza az e-government, e-governance és e-administration kifejezések jelentését, feltárja e tevékenységek közötti eltéréseket, ami azért szükséges, hogy a további vizsgálatok körét pontosabban le 
lehessen határolni. Ezt követően bemutatom az elektronikus közigazgatás témakörével foglalkozó diszciplínák fogalomértelmezéseit, továbbá azt, hogy milyen aspektusból vizsgálják az e-közigazgatást. Végül a tanulmány arra keresi a választ, hogy a területi kutatásoknak (a földrajztudománynak és a regionális tudománynak) lehet-e szerepe, és ha igen, milyen vizsgálati kérdések megválaszolására ebben a témakörben.

\section{Elektronikus közigazgatás, elektronikus kormányzás, elektronikus ügyintézés}

Az Egyesült Nemzetek Szervezte 2001 óta évente kiszámítja és közli 191 tagállamra vonatkozó e-közigazgatási készenléti indexét (Tózsa 2012). Az első, 2001ben megjelent tanulmányban tesznek kísérletet a fejezetcímben szereplő fogalmak közötti különbségtételre. Az ENSZ magyarázata alapján a kormányzás (governance) olyan folyamat, eljárás, amelynek során a közszféra és a társadalom interakcióba kerül. Az elektronikus kormányzás célkitűzése, hogy a leginnovatívabb információs kommunikációs technológiák alkalmazásával nyújtson az állampolgárok számára továbbfejlesztett szolgáltatásokat; átadjon megbízhatóbb információkat, szélesebb körű ismereteket, tudást, amelyeken keresztül a kormányzási folyamatokhoz való hozzáférést megkönnyítik és elősegítik a „mélyebb” állampolgári részvételt. A digitális kormányzásnak van lehetősége arra, hogy kapcsolatba kerüljön az állampolgárokkal és ezáltal egyenlő jogot biztosítson a döntéshozói folyamatokban való részvételre, ami közvetetten és közvetlenül is hathat a politikai folyamatokra (UN 2002). Palvia és Sharma (2007) szintén azt fogalmazzák meg, hogy az e-kormányzás támogatja az állampolgárok nagyobb, szélesebb körü részvételét a politikai szervezetek tevékenységében például azáltal, hogy a politikai pártok és szereplők megjelennek az interneten és ezzel az eszközzel próbálják választókerületük nézeteit megismerni. Az elektronikus kormányzás megvalósításának célja az is, hogy támogassa a „jó kormányzást” (good governance), amely a részvétel, az átláthatóság és a felelősség elvén alapul. Az információs kommunikációs technológiák lehetőséget nyújtanak arra, hogy átalakítsák az állampolgárok és a kormányzás közötti kapcsolatokat (portal.unesco.org). Rossel és Finger (2007) tanulmányában jelenik meg az a gondolat, hogy az e-kormányzásnak többnek kell lennie, mint egy szinonimának: az nem az e-közigazgatás és e-ügyintézés megfogalmazásának másik útját jelenti, hanem más látásmódot közvetít. Míg az e-közigazgatás a szerzők szerint „puszta” elektronizációt jelent, addig az e-kormányzás nemcsak szervezeti és intézményi szempontból javítja a hatékonyságot, hanem a politikai döntéshozatalban és a szabályozási feladatokban is egyre nagyobb a szerepe a technológiai innovációnak, megvalósítva ezzel egy valóban többszintű, több területre kiterjedő, több résztvevős tevékenységet. 
A government fogalma amerikai szóhasználatban a hatalmi szervek és funkciók egészét átfogja, a szövetségi kormány különböző szerveitől a legkisebb helyi szervezetekig kiterjed, magyarul leginkább a közigazgatás szó közelíti meg ezt a jelentést (Osborne, Gaebler 2007). Az elektronikus közigazgatás általános kifejezés a különböző területi szintek közigazgatási szerveinek webes szolgáltatásaira. Az államigazgatás információs kommunikációs technológiákat alkalmaz azért, hogy támogassa az államigazgatási szervek múködését, szolgáltatásokat nyújtson az állampolgároknak (Palvia, Sharma 2007). Az ENSZ 2002-es tanulmánya (UN 2002) azt fogalmazza meg, hogy az e-közigazgatásra a szervezetek közötti kapcsolatok a jellemzőek, beleértve ebbe a politikai koordinációt, a politikai végrehajtást és az online szolgáltatások nyújtását az állampolgároknak. Arra ösztönzik az állampolgárokat, hogy nagyobb mértékben használják az online szolgáltatásokat, ennek érdekében mérik ezek hatékonyságát és eredményességét, valamint felülvizsgálják, értékelik a portálokat. Alapvetően az e-közigazgatás azonosítható azzal az általános célkitűzéssel, hogy a közszféra eredményességét és hatékonyságát az információs kommunikációs technológiák alkalmazásán keresztül fejlesztik (Jeong 2007).

Az e-administration, e-ügyintézés kifejezések sokkal csekélyebb számban jelennek meg mind a nemzetközi, mind a hazai szakirodalomban. Az e-ügyintézés az ENSZ 2002-es tanulmánya alapján az egy szervezeten belül zajló interakciókat jelöli (UN 2002). Az e-ügyintézés jelöli azt a folyamatot, amikor az egyes szervezeteken belül zajló papíralapú ügyintézés (pl.: építésügy) elektronikussá válik (wisegeek.com). Ennek alapvetően két célja van: egyrészt az adminisztrációs terhek csökkentése a közigazgatási intézményeken belül, másrészt ezeknek az adminisztratív folyamatoknak hatékonyabbá, eredményesebbé tétele (jisc.ac.uk).

A tanulmány fókuszában az elektronikus közigazgatás (e-government) vizsgálata áll, így a továbbiakban az elektronikus kormányzás (e-governance) kifejezést az eltérések tisztázása után nem alkalmazom. Az elektronikus ügyintézés (e-administration) értelmezésem szerint az elektronikus közigazgatás részhalmaza, ezért azt továbbra is használom.

A három definíció ismertetése során többször előkerült a kölcsönös viszony, interakció fontossága. Az e-government egyik legfontosabb aspektusa, hogy hogyan tudja közelebb hozni a közigazgatási szervekhez az állampolgárokat és az üzleti élet szereplőit. Fang (2002) a közigazgatás szereplői és a kapcsolatok irányai alapján nyolcféle digitális interakciót különböztet meg:

- állampolgárok és a kormányzat közötti kapcsolatok ( $\mathrm{G} 2 \mathrm{C}$ - government to citizens, C2G - citizens to government);

- gazdasági szereplők és a kormányzat közötti kapcsolatok (G2B - government to business, B2G - business to government);

- civil szervezetek és a kormányzat közötti kapcsolatok (G2NGO - government to non-governmental organizations, $\mathrm{NGO2G} \mathrm{-} \mathrm{non-governmental} \mathrm{organizations}$ to government); 
- közigazgatási szervezetek közötti kapcsolatok (G2G - government to governments);

- közszolgálatban dolgozók közötti kapcsolatok (G2E - government to employees).

Az interakciók áttekintéséhez nyújt segítséget az 1. ábra, amelyben a szereplők és a közöttük megvalósuló interakciók irányai mellett látható az e-közigazgatás és az e-ügyintézés halmaz-részhalmaz viszonya is.

Tapscott (1998) megállapítja, hogy az e-közigazgatás fejlődése hasonlóságot mutat az elektronikus kereskedelem fejlődésével. Az elektronikus kereskedelem lehetővé tette, hogy a vállalkozások kommunikációjuk során közelebb kerüljenek egymáshoz, és üzleti kapcsolataik hatékonyabbá váljanak (B2B). Emellett a fogyasztók is közelebb kerültek a szolgáltatókhoz és a szolgáltatásokhoz, így egyes szolgáltatások ára csökkenhetett a minőség emelkedésével egyidejüleg (B2C). Az e-közigazgatás ehhez hasonlóan alkalmas arra, hogy megteremtse az államigazgatás és az állampolgárok közötti interaktív kommunikáció lehetőségét (G2C), valamint az állam és a vállalkozások közötti kapcsolatteremtést is megreformálhatja (G2B). Mindezek mellett az állami szervek egymás közötti, állami szférán belüli kommunikációja is megújulhat (G2G). A fentiek következtében a közigazgatás működése ügyfélközpontúbbá, átláthatóbbá és kevésbé költségessé válhat. Az alapvető különbséget az e-kereskedelem és az e-közigazgatás folyamatainak intenzitása között az okozza, hogy míg az informatikai fejlődés mozgatórugója a profitorientált versenyszféra, addig a közigazgatás-szervezésből épp ez a legnagyobb ösztönző erő, a profit hiányzik (Csáki 2009).

1. ábra: A közigazgatásban lejátszódó digitális interakciók szereplői és irányai Digital relationship between citizens, business and government

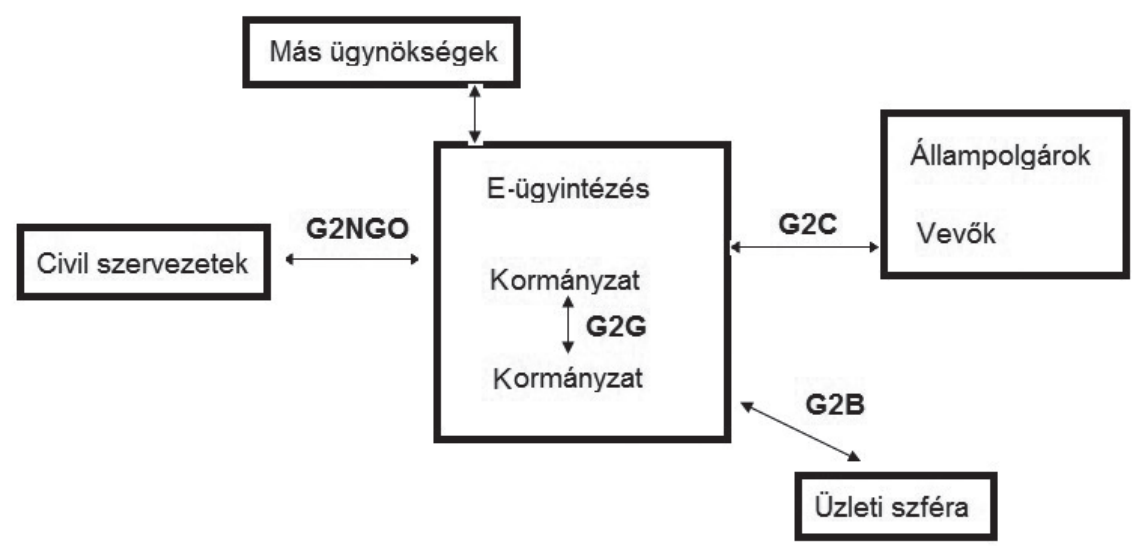

Forrás: Heeks 2006. 


\section{Diszciplínánkénti fogalomértelmezések}

A tudománytörténeti megközelítés nem szó szerint magyarázza az elektronikus közigazgatás definícióját, hanem előrevetíti azokat a társadalmi-gazdasági változásokat, amelyek az információs társadalom és annak a része, az elektronikus közigazgatás kialakulásához közvetetten kötődnek. Az információs társadalom kifejezése 1963 óta ismert, ezt megelőzően alkotják meg a tudástársadalom, tudásgazdaság, tudásmunkás kifejezéseket (Jakobi 2007). Fritz Machlup munkásságát és a Tudás termelése és elosztása az Egyesült Államokban című munkáját tekinti a szakirodalom olyan mérföldkőnek, amely az információs társadalom fogalmának megszületéséhez vezetett. Machlupot az „alapító atyák” egyikének tartják, annak ellenére, hogy munkájában nem használja az információs társadalom kifejezést, hanem a "tudásipar” „kvantitatív történetét” vázolja fel (Z. Karvalics 2009a). Az információs társadalom historiográfiájából szinte teljes mértékben hiányzik, de a társadalomtudományok sem fedezték fel maguknak, hogy Jean Gottmann (1915-1994) francia geográfus 1961-es Megalopolisz címü munkájában megfogalmazza, hogy az ipari korszakra jellemző viszonyok napja leáldozott, az „új” folyamatok az általa vizsgált Washington és Boston közötti összefüggő városiasodott övezetben (amelyet Megalopolisznak nevezett el) formálódnak, ott tanulmányozhatók a legjobban. Ahogy kortársai, Gottmann sem ír az információs társadalom kialakulásáról, hanem posztindusztriális társadalomról és átalakulásról beszél, amelyet a fehérgallérosok forradalmának nevez el. Ebben az 1961-es munkában már megfogalmaz olyan tételeket, melyek szerint a kialakuló szolgáltató szektor alapvetően a kommunikációra orientálódik és elsősorban az információáramlás szempontjából vizsgálandó. Gottmann hívástérképeket elemez könyvében: a telefonos kommunikáció a Megalopoliszban koncentrálódik, ott éri el legnagyobb sűrűségét. A telefonforgalom két nagy elosztó központja, amelyet ma hálózati csomópontnak neveznének, New York és Boston. A földrajzi lokalizálás mellett Gottmann megállapítja, hogy a telefonhívások ${ }^{1}$ zöme a fehérgalléros hivatásokhoz kötődik (Z. Karvalics 2009b). Tehát a hatvanas években egy geográfus fogalmazta meg és vizsgálta az információs társadalom jelenségeit és elemeit. A posztindusztriális, tudásra alapozott, globális gazdaság kialakulása világszerte megváltoztatta a körülményeket, problémákat hozott létre és új lehetőségeket teremtett, ezekre a kihívásokra a közigazgatásnak is válaszolnia kell (Osborne, Gaebler 1994). A tanulmánynak nem célja az információs társadalom definíciójának tudománytörténeti áttekintése, mindössze a földrajztudományban való korai megjelenésének a felvillantása volt a szándékom.

Az informatika fejlődése és az infokommunikációs technológiák elterjedése sok olyan új fogalmat és elnevezést teremtett, amelyek a jogban, különösen a közigazgatási jogban nehezen adaptálhatók. A jogi szabályozás folyamatos és kényszerü lemaradásra van kárhoztatva a terület rohamos ütemü fejlődése miatt (Csáki 2009). A technikai, technológiai fejlődés gyakorlatilag exponenciá- 
lis, ezt az iramot pedig egyre nehezebben követi a jogi szabályozás (Csáki 2006). A jogorvoslatban például olyan új problémák jelennek meg, amelyek újszerü megoldásokat és látásmódot igényelnek. A magyar jogi szakirodalomban az e-közigazgatás definiálása alig jelenik meg, Csáki 2009-es doktori értekezésében igyekszik tisztázni a fogalom jelentését és elhelyezni azt a közigazgatási jog diskurzusában. Véleménye szerint általános értelemben véve az elektronikus közigazgatás lényege, hogy alkalmazzák a technikai fejlődés nyomán megjelent információs és kommunikációs technológiákat a közigazgatásban, ami új távlatokat nyit, új jogintézmények kialakítására ad lehetőséget, valamint segíti a meglévő jogintézmények érvényesülését. Csáki szerint nem létezik egységes, nemzetközileg is alkalmazható modellje az e-governmentnek, mivel minden államban eltérő kultúrával találkozhatunk, más az alkotmányos berendezkedés, eltérőek a politikai és jogi keretek. Ezért úgy gondolja, hogy minden államnak magának kell eldöntenie, hogy az e-government kiépítése során milyen prioritásokat vesz figyelembe (Csáki 2009). Dósa és Polyák (2003) azt fogalmazzák meg, hogy az elektronikus közigazgatás olyan modernizációs folyamat, amely érinti a közigazgatás minden szintjét, és végső soron átalakítja a kapcsolatrendszereket. Ahhoz, hogy az elektronikus közigazgatási szolgáltatások minden szinten megfelelően tudjanak működni, elengedhetetlen a jogi szabályozás - bár az e-közigazgatás nem kizárólag és nem elsősorban szabályozási kérdés.

Míg a jogtudomány az elektronikus közigazgatás jogi környezetét, hátterét szolgáltatja, addig a közgazdaság-tudományok - azon belül is az igazgatásszervezés és a szervezéstudományok - hatékony szervezeti és kormányzati struktúrákat fejlesztenek a közszféra számára. A szakterület kulcsfeladatai közé tartozik a ,jó kormányzás", a kormányzati modernizáció megvalósítása, az elszámoltathatóság, az átláthatóság, valamint a szolgáltatások minőségének a fejlesztése. Feladatainak részét képezi továbbá a teljesítményértékelés (Codagnone, Wimmer 2007). Budai (2008) doktori értekezésében úgy fogalmaz: „Az információs társadalom olyan új társadalmi együttélési forma, melynek során - napjainkban - az infokommunikációs eszközök, az eszközökhöz rendelt tartalom, az ezeket működtetni képes ismeret olyan tudást, majd innovációt generál, mely katalizálja és újraszervezi a gazdasági-társadalmi és kulturális folyamatokat (a társadalmi [és területi - kiegészítés tőlem] egyenlőtlenségek sajnálatos újratermelése mellett), s ezekhez új tartalmi és formai szabályozást és igazgatást (gyakori, dinamikus korrekcióval) követel. A valamennyi szférát érintő átalakulásban a közigazgatás elé támasztott kihívásokat az e-közigazgatás tágan értelmezett eszközrendszere (szervezési-vezetési módszerei, technológiai megoldásai, jogi szabályozása) oldja meg, új alapokra helyezve a közigazgatást." (Budai 2008, 27.) Tehát az elektronikus közigazgatás igazgatásszervezési válasz az információs társadalom különböző jelenségeire, kihívásaira (Budai, Tózsa 2007). A szakma képviselőinek a feladata az, hogy az elektronikus átállást azáltal gyorsítsák fel, hogy a munkaszervezés és szervezetfejlesztés területén kísérleti alkalmazásokkal beillesztik az elektronizációt a jelenlegi igazgatási folyamatokba és szervezetekbe (Tózsa 2012). 
Az e-közigazgatást erősen átszövi az információs társadalmi szakpolitika. Számos fejlesztési, stratégiai dokumentum született a tárgykörben, nemzetközi szervezetek is alkottak fogalommagyarázatokat. A Világbank értelmezése szerint az elektronikus közigazgatás az igazgatási intézmények információstechnológia-használatát (pl.: széles sávú internet, mobiltechnológiák) jelenti, amely lehetővé teszi, hogy az állampolgárok, a kormány és az üzleti szféra a virtuális téren keresztül közelebb kerüljön egymáshoz. Ez a „közelítés” megvalósulhat akár egy helyi kioszkban, vagy az otthonunkban, irodánkban lévő számítógépen keresztül is (web.worldbank.org).

Az Európai Unió álláspontja szerint az elektronikus közigazgatásnak három tevékenységet kell magába foglalnia: az infokommunikációs eszközök alkalmazását a közigazgatásban, ezzel a modernizációval összefüggően szükséges a munkafolyamatok és müködési egységek átszervezése, továbbá a közigazgatásban dolgozók (közalkalmazottak, köztisztviselők) és az ügyfelek (állampolgárok) képzése, hogy az új technológia aktív felhasználóivá válhassanak (Molnár 2007). Az Európai Bizottság szerint az e-közigazgatásnak nyitottnak és átláthatónak kell lennie (a közigazgatás legyen képes megérteni az állampolgárok igényeit), ez az innováció nem zárhat ki senkit (személyre szabottan, társadalmi, területi helyzettől függetlenül a lakosság minden szegmensét meg kell szólítania), valamint hatékonynak kell lennie, azaz fontos, hogy képes legyen időt és pénzt megtakarítani (Molnár 2007). Az Európai Unió információs társadalmi szakpolitikájának egyik legfőbb hívószava az e-befogadás (e-inclusion) politika. $2008 \mathrm{az}$ e-befogadó információs társadalom éve volt az Európai Unióban, a politika fó célkitüzése, hogy megakadályozzák az információs kommunikációs technológiák használata miatt felerősödött társadalmi és gazdasági különbségek növekedését (Dombi, Molnár 2008), amelyek hatással vannak a területi egyenlőtlenségek alakulására is. Ennek elérése érdekében 2006-ban a rigai nyilatkozatban világos és jól mérhető célokat fogalmaztak meg, amelyek között a digitális írástudás növelése és a különböző társadalmi csoportok között húzódó internethasználati egyenlőtlenségek csökkentése mellett szerepel a földrajzi szakadék leküzdése: csökkenteni kell az internetelérhetőség regionális különbségeit, valamint növelni a széles sávú lefedettséget. A felsorolt célok között megjelenik a befogadó e-közigazgatás megvalósítása: támogatják és biztosítják a közszféra honlapjainak elérhetőségét, továbbá felhasználó-központú szolgáltatásokat nyújtanak (Codagnone 2009). A digitális szakadék a legfőbb kihívások egyike, amellyel a közszféra szervezetei az e-közigazgatás megteremtésével oly módon tudnak szembenézni, hogy támogatják az online szolgáltatások elterjesztését és használatát az állampolgárok között. Ezek az innovatív technológiák képesek arra, hogy a digitális szakadékot digitális lehetőséggé (digital opportunity) formálják át (Weerakkody, Dwivedi, El-Haddadeh, Almuwil, Ghoneim 2012).

Felvázolva a különböző diszciplínák elektronikusközigazgatás-értelmezését és az ahhoz kötődő vizsgálati irányaikat, levonható az a következtetés, hogy a földrajz és a regionális tudomány nyelvezetéhez közel állnak a közgazdaság- 
tan és azon belül az igazgatásszervezés értelmezései, hiszen társadalmi egyenlőtlenségekről is beszélnek. Legközelebbi területnek a szakpolitikák és az azokhoz kötődő tudományos vizsgálatok irányai állnak, mivel fogalmaik, célkitűzéseik és vizsgálati módszereik hasonlítanak a földrajz és a regionális tudomány egyes elemeihez. A következőkben arra keresem a választ, hogy milyen vizsgálati lehetőségei, szerepe és feladatai vannak az elektronikus közigazgatás tárgykörében a geográfiának és a regionális tudománynak. A kérdés megválaszolásához először áttekintem a közigazgatás földrajzának fogalmát és történeti fejlődését, majd végiggondolom, hogy a megváltozott körülmények, az új infokommunikációs technológiák alkalmazása a közszférában mennyiben módosítja a közigazgatás földrajzának vizsgálati tárgykörét.

\section{A közigazgatási földrajz és az elektronikus közigazgatás kapcsolata}

A közigazgatás Magyary Zoltán megfogalmazásában „az állam adminisztrációja”, a közfeladatok megoldása, a természetük által megszabott módszerrel a jogrend keretein belül (Magyary 1942). Az államterület közigazgatási területegységekre oszlik (leszámítva a törpe- és városállamokat), ezekhez az egységekhez kötődik a közfeladatok megoldása: a társadalom életének szervezése, irányítása, valamint politikai berendezkedésétől függően akár az ellenőrzése is (Agg 1998). A közigazgatási területbeosztás kialakulására hatnak a történelmi folyamatok, a történetileg kialakult struktúrák (Hajdú 2001). Az állami irányítás térbeli egységei közül kettőt tekinthetünk megkerülhetetlen történeti adottságnak: az országhatárt és a településhatárt. E két szint közé legalább egy közigazgatási, területi szintet közbeiktatnak (Agg 1998), a közöttük lévő irányítási egységek kialakítását a hatalmi viszonyok, társadalmi, csoport- és egyéni érdekek is befolyásolják (Pálné Kovács 2013). E tényezők mellett a közigazgatási területbeosztásra jelentős hatást gyakorol a termelőerők fejlődése és fejlettsége, a területi munkamegosztás kialakult rendje, az államterület természeti, gazdasági, közlekedési és településhálózati struktúrája, a népesség száma és területi eloszlása. A felsorolt elemek és hatásmechanizmusaik korszakonként változnak (Hajdú 2001).

A közigazgatási területbeosztás tanulmányozásához el kell különíteni két téregységet: az általános beosztást (a társadalmi struktúrák teljessége miatt ennek a felosztásnak nagyobb a jelentősége, a tanulmányban ezt értem a közigazgatási térbeosztás fogalma alatt), valamint az ágazati területi beosztást, amelynek az adott ágazat közigazgatási rendjén belül van meghatározó szerepe. A közigazgatási területbeosztás alakulásának, hatásainak, határainak és tartalmának vizsgálata számos más tudományterület mellett fontos kérdése a földrajztudománynak (Hajdú 2001). A közigazgatási földrajz legfőbb kérdésfelte- 
vése, hogy „megfogalmazható-e, s ha igen, milyen alapokon az az általános érvényű térkategória, illetve térrendszer, melyre a közigazgatási beosztás racionálisan felépíthető, s társadalmilag elfogadható." (Hajdú 2001, 37.).

A közigazgatás- és a földrajztudomány közötti kapcsolat a történeti fejlődés során többször változott. A modern közigazgatási földrajz előzményeinek számítanak az államismereti művek, amelyekben az államterületről kívántak földrajzi és nem földrajzi ismereteket nyújtani. Ezekben a leíró jellegű művekben megjelent az adott állam természeti, gazdasági, népességi, települési, politikai, közigazgatási viszonyainak ismertetése. A közigazgatási földrajz kérdéseinek kutatása az 1. világháború alatt és utána került előtérbe (egyrészt a háborús erőfeszítések fokozása érdekében, másrészt a háború után jelentkező közigazgatási reformtörekvések kapcsán). A két világháború közötti időszakban elmélyültek a közigazgatási földrajzi kutatások, ezt a folyamatot meghatározta a földrajz ideológiai-politikai megosztottsága, de ekkor elméleti kutatások is megjelentek. A közigazgatási földrajzi kutatások összekapcsolódtak a területfejlesztési, regionális tervezési és fejlesztési kutatásokkal. Az 1960-as években a kvantitatív forradalom hatása elérte a közigazgatási földrajzot is, módszereiben elkezdett megújulni ez a tudományterület, megjelentek a matematikai és geometriai alapokon nyugvó térmodellek. Az 1980-as évek a közigazgatási földrajz nemzetközi intézményesülésének időszaka, ekkor alakult meg a Nemzetközi Földrajzi Unióban először egy munkacsoport, majd a „Földrajz és Közigazgatás Munkabizottság”, amely keretbe foglalja és összehangolja a közigazgatási földrajzi kutatásokat. A közigazgatási földrajz fejlődésére hatással volt a földrajztudomány három nagy elmélete (a tájelmélet, a gazdasági körzetelméletek és a központi helyek elmélete). A három elmélet közigazgatási földrajzon belül való megjelenésének közös eleme, hogy a közigazgatási teret csak hierarchikus, illeszkedő területi rendszerként tagolják. Napjainkban is megjelennek a három gondolatrendszernek egyes elemei a közigazgatási földrajz kutatásában, a kiemelt részelemeket szintetizálják és a közigazgatási térszervezés gyakorlati problémáinak megoldásához alkalmazzák azokat (Hajdú 2001), bár a közigazgatási területbeosztás nem feltétlenül igazodik a tájegységekhez, a gazdasági és ellátási vonzáskörzetekhez (Agg 1998). A közigazgatási földrajz kutatásában két alapprobléma jelenik meg: az államterület helyi (települési), területi és központi szintekre tagolódik, helyi és központi szintre minden esetben szükség van, de a területi szintek esetében kérdéses azok száma és jellege. A másik nehézség a szinteken belüli horizontális lehatárolás problémájából ered: szinte lehetetlen a térkategória tartalmával átlapoló viszonyban lévő területegység-nagyságot meghatározni. A tartalomhoz képest meghatározott területegységek az ideális átlapoló viszony mellett lehetnek alulhatároltak és túlhatároltak (Hajdú 2001).

A közigazgatás térbeli szerkezete a léptékváltás (rescaling) nyomán megváltozik (Pálné Kovács 2013). Azáltal, hogy a hatalom „átlép” egyik szintről a másikra, átstrukturálódik a hatalom szerkezete, megváltozhatnak a kormányzási és a szabályozási metódusok (Swyngedouw 2000). A léptékváltás jelenségé- 
nek vizsgálata összekötődik a kormányzás új gyakorlatainak, szerkezetének elemzésével, és magába foglalja a földrajzi, térkategóriaméret-változást, valamint a tartalmi változást is (Gualini 2006). Ilyen léptékváltás lehet a regionalizácó, valamint a hetvenes évektől megerősödő szupranacionális (államterület feletti) szint megjelenése is. Az ezredforduló környékén megfogalmazódott, hogy a legjobb gyakorlatok terjesztése már nem elegendő tagállami szinten, hanem szupranacionális támogatás szükséges hozzá. A világ közigazgatásában tapasztalható egységesülési folyamat egyik kulcsfogalmává vált a „jó kormányzás” (Pálné Kovács 2013). A jó kormányzás reformjának fontos részét, „ideáját” képezi az új közszféramenedzsment (new public management) (Jansen 2007). Az 1970-es évek válságai a közszolgálati szektorra is hatással voltak, elsőként Nagy-Britannia és az Egyesült Államok indítottak nagyszabású reformprojekteket a közszektor modernizációjára. A modernizálás alapelmélete az új közszféramenedzsment, amely a piaci, magánszektor technikáit átvéve szeretné a közszférát hatékonyabbá ${ }^{2}$ tenni (Heeks 2001). Henman (2010) az elektronikus közigazgatást az új közszféramenedzsment szerves részének tekinti, úgy véli, hogy az információs kommunikációs technológia eszköz arra, hogy megvalósulhasson a piaci szektorhoz hasonló hatékonyabb közszféra. Ezen túlmenően Dunleavy, Margetts, Bastow és Tinkler (2006) úgy vélekednek, hogy az elektronikus közigazgatás már túl is nőtt az új közszféramenedzsmenten: nemcsak eszközként, szolgáltatásként tekintenek az információs kommunikációs technológiákra, hanem kijelentik, hogy az új közszféramenedzsment halott, helyét a digitális kor kormányzása (digital-era governance) veszi át.

A korábban említett nemzetközi szervezeti ajánlások és a közszféra reformját átható elméletek mind azt sugallják, hogy a (területi) közigazgatás és az elektronikus közigazgatás gondolata összefonódik, így azt gondolom, hogy a közigazgatás földrajzának is érdemes foglalkoznia ezzel a gondolatkörrel. A magyar államtörténeti és belső politikai fordulatok okán csak a 20. század során legalább hat területi átstrukturálódás ment végbe a közigazgatásban (Hajdú 2001). A „legfrissebb” területi közigazgatási változás a járási rendszer bevezetése 2013. január 1-jével, amely része a Magyary Zoltán közigazgatás-fejlesztési programnak. A rendszer koncepciójáról a Nemzeti Közigazgatási Intézet megbízásából készült tanulmány a járások lehatárolásának szempontjai között nem említi az elektronizálási folyamatot, az infokommunikációs technológiák infrastruktúrájának felmérését (Csite, Oláh 2011). A tanulmányban utazási költség, munkabérveszteség és időveszteség alapján készítenek becsléseket a járási központok optimális lehatárolásának érdekében. A koncepcióból hiányzik annak átgondolása, becslésekben való megjelenítése, hogy egy jól működő elektronikus közigazgatási rendszer kialakítása (infrastruktúra, képzési költségek, marketing) hosszú távon hozhatna-e nyereséget (ezzel mind utazási költséget, mind munkabér- és időveszteséget lehetne csökkenteni, hiszen az ügyintézés nem helyhez kötött és gyorsabbá válik). 


\section{Összegzés}

A tanulmány választ kívánt adni arra a kérdésre, hogy a területi kutatásoknak (a földrajznak és a regionális tudománynak) van-e létjogosultsága az elektronikus közigazgatás vizsgálatára. A tanulmány első harmadában tisztáztam az elektronikus közigazgatás fogalmát, a második harmadában sorra vettem azon főbb szakterületeket, amelyek ennek a témának a vizsgálatával foglalkoznak, a harmadik harmadában pedig a közigazgatási földrajz történeti áttekintésével foglalkoztam. A 2. ábra összefoglalja, hogy mely szakterületek érintik az elektronikus közigazgatás vizsgálatát, kiemelve a közigazgatás földrajzának feladatait.

Az igazgatásszervezés és a szakpolitikai vizsgálatok is megfogalmazzák, hogy a legfőbb kihívások egyike a befogadó e-közigazgatás megteremtése, a digitális szakadék leküzdése, amely társadalmi, gazdasági és területi különbségekben egyaránt megnyilvánul. A földrajznak és a regionális tudománynak ezeknek a területi különbségeknek a feltárásában és mérséklésében lehet szerepe. A közigazgatási földrajz kutatásában általánosságban két alapprobléma jelenik meg: a területi szintek számának és jellegének meghatározása, valamint a horizontális lehatárolás problémája. A közigazgatás-fejlesztési folyamatokat erősen áthatja az elektronizáció, így a közigazgatási földrajzi vizsgálatok során térkategóriák lehatárolásakor és meghatározásakor érdemes lehet a tér- és idöbeli elérések mellett a virtuális tér jelenségét is figyelembe venni, integrálni.

2. ábra: Az elektronikus közigazgatást vizsgáló szakterületek Disciplines related to the examination of e-government

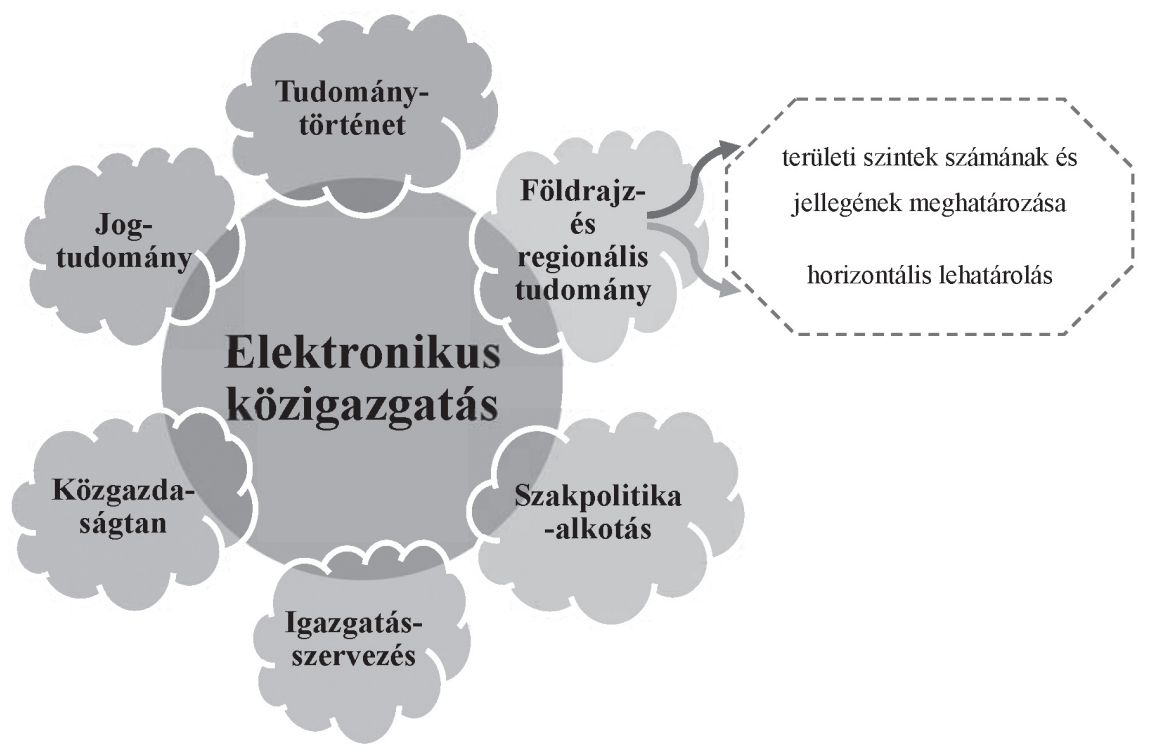




\section{Jegyzetek}

1 Walter Christaller 1933-as, a központi helyek elméletéről szóló tanulmányában is fontos szerep jut a telefonvonalaknak, bár ebben a műben a telefonvonalak száma mint infrastruktúra, nem pedig a hívások sűrűsége (a kommunikáció) fontos, továbbá a kontextus sem az információs társadalom. Ennek ellenére Christaller is a technológiai innováció egyik elemét, a telefonvonalak számát elemzi.

2 A hatékonyságot és az eredményességet már Magyary is elsődleges követelményként fogalmazta meg a közszférával szemben (Pálné Kovács 2011).

\section{Irodalom}

Agg Z. (1998): Közigazgatási ismeretek geográfusoknak. ELTE Eötvös Kiadó, Budapest

Balogh G. (2006): Egy túlterhelt fogalom. Információs Társadalom, 1., 22-29.

Budai B. B. (2008): E-közigazgatás axiomatikus megközelítésben. Doktori értekezés. Pécsi Tudományegyetem, Állam- és Jogtudományi Doktori Iskola, Pécs

Budai B. B. (2009): Az e-közigazgatás elmélete axiomatikus megközelítésben. Információs Társadalom, 2., 68-79.

Budai B. B., Tózsa I. (2007): E-közigazgatás. DE AMTC AVK, Debrecen

Codagnone C. (ed.) (2009): Vienna study on inclusive innovation for growth and cohesion: Modelling and demonstrating the impact of $e$-inclusion. European Commission, Brussels

Codagnone, C., Wimmer, M. A. (eds.) (2007): Roadmapping eGovernment research. Visions and measures towards innovative governments in 2020. eGovRTD2020 Project Consortium

Csáki Gy. B. (2006): Elektronikus közigazgatás - vízió és valóság. Sectio Juridica et Politica, 24., 191-198.

Csáki Gy. B. (2009): Az elektronikus közigazgatás tartalma és gyakorlatának egyes kérdései. Doktori értekezés. Pécsi Tudományegyetem, Állam- és Jogtudományi Doktori Iskola, Pécs

Csite A., Oláh M. (szerk.) (2011): Kormányozni lehet ugyan távolról, de igazgatni csak közelról lehet jól. A területi közigazgatás reformját elősegítő tanácsadás a modern kori járások központjainak és lehatárolásának tárgyában című projekt résztanulmánya. Kézirat.

Dinesh, C. M. (2007): Defining e-government: A citizen-centric criteria-based approach. In: Proceedings of the 10th National Conference on e-Governance, Bhopal, Madhya Pradesh

Dombi G., Molnár Sz. (2008): A digitális megosztottság fogalmától az e-inclusion politikájáig. Információs Társadalom, 2., 7-16.

Dósa I., Polyák G. (2003): Informatikai jogi kézikönyv. KJK-Kerszöv, Budapest

Dunleavy, P., Margetts, H., Bastow, S., Tinkler, J. (2006): New public management is dead - long live digital-era governance. Journal of Public Administration Research and Theory, 3., 467-494.

Fang, Z. (2002): E-government in digital era: Concept, practice, and development. International Journal of the Computer, the Internet and Management, 2., 1-22.

Gualini, E. (2006): The rescaling of governance in Europe: New spatial and institutional rationales. European Planning Studies, 7., 881-905.

Hajdú Z. (2001): Magyarország közigazgatási földrajza. Dialóg-Campus Kiadó, Budapest, Pécs

Heeks, R. B. (2001) Reinventing government in the information age. In: Heeks, R. B.: Reinventing government in the information age. Routledge, London, 9-21.

Heeks, R. B. (2006): Implementing and managing e-government: An international text. Sage, London

Henman, P. (2010): Governing electronically: E-government and the reconfiguration of public administration, policy, and power. Palgrave Macmillan, Basingstoke

Jakobi Á. (2007): Az információs társadalom térbelisége. ELTE Regionális Tudományi Tanszék, Budapest (Regionális Tudományi Tanulmányok; 13.) 
Jansen, D. (ed.) (2007): New forms of governance in research organisations. Springer, Dordrecht Jeong, C. H. I. (2007): Fundamental of development administration. Scholar Press, Selangor Magyary Z. (1942): Magyar közigazgatás. Királyi Magyar Egyetemi Nyomda, Budapest Molnár Sz. (2007): E-közigazgatás az Európai Unióban. Budapest

Osborne, D., Gaebler, T. (1994): Új utak a közigazgatásban. Vállalkozói szellem a közösségi szektorban. Kossuth Kiadó, Budapest

Pálné Kovács I. (2011): Magyary Zoltán és a magyar közigazgatás. Tér és Társadalom, 3., 173-179.

Pálné Kovács I. (2013): Közigazgatási földrajz. In: Jeney L., Kulcsár D., Tózsa I. (szerk.): Gazdaságföldrajzi tanulmányok közgazdászoknak. Budapest Corvinus Egyetem, Gazdaságföldrajzi és Jövőkutatási Tanszék, Budapest, 285-303.

Palvia, S. C. J., Sharma, S. S. (2007): E-government and e-governance: Definitions, domain framework and status around the world. Foundation of E-government

Rossel, P., Finger, M. (2007): Conceptualizing e-government. In: ICEGOV '07 Proceedings of the 1st International Conference on Theory and Practice of Electronic Governance. ACM, New York, 399-407.

Swyngedouw, E. (2000): Authoritarian governance, power, and the politics of rescaling. Environment and Planning D. Society and Space, 1., 63-76.

Tapscott, D. (1998): Blueprint to the digital economy. McGraw-Hill, New York

Tózsa I. (2012): Az elektronikus közigazgatás helyzete. Új Magyar Közigazgatás, 2., 2-12.

UN [United Nations] (2002): Benchmarking e-government: A global perspective. Assessing the UN Member States. United Nations Division for Public Economics and Public Administration, American Society for Public Administration

Weerakkody, V., Dwivedi, Y. K., El-Haddadeh, R., Almuwil, A., Ghoneim, A. (2012): Conceptualizing e-inclusion in Europe: An explanatory study. Information Systems Management, 4., 305-320.

Z. Karvalics L. (2009a): A tudás termelése és elosztása az Egyesült Államokban: Fritz Machlup újraértékelése az információs társadalom elmélettörténetében. Információs Társadalom, 2., 20-34.

Z. Karvalics L. (2009b): A fehérgalléros forradalom krónikája. Jean Gottmann, az információs társadalom elméletének elfeledett úttörője. Információs Társadalom, 3., 53-66.

http://portal.unesco.org/ci/en/ev.php-URL_ID=4404\&URL_DO=DO_TOPIC\&URL_SECTION=201.html (Letöltés: 2013. május 20.)

http://www.jisc.ac.uk/whatwedo/themes/eadministration.aspx\# (Letöltés: 2013. május 25.)

http://web.worldbank.org/WBSITE/EXTERNAL/TOPICS/EXTINFORMATIONANDCOMMUNICATIONANDTECHNOLOGIES/EXTEGOVERNMENT/0,,contentMDK:20507153 menuPK:702592 pagePK:148956 piPK:216618 theSitePK:702586,00.html (Letöltés: 2013. május 25.)

http://www.wisegeek.com/what-is-e-administration.htm (Letöltés: 2012. május 25.) 